\title{
The Role of Dynamic Capabilities in Export Performance of Firms from Emerging Economies
}

\author{
Dissatat Prasertsakul ${ }^{1}$ \\ ${ }^{1}$ Mahidol University International College, Mahidol University, Thailand \\ Correspondence: Dissatat Prasertsakul, Mahidol University International College, Mahidol University, Thailand. \\ E-mail: dissatat.pra@mahidol.ac.th
}

Received: June 20, 2013

Accepted: July 10, 2013

Online Published: July 26, 2013

doi:10.5539/ ibr.v6n8p102

URL: http://dx.doi.org/10.5539/ ibr.v6n8p102

\begin{abstract}
Increased globalisation has led to a great number of firms looking for opportunities abroad, and exporting is the most common form of entry mechanism. The purpose of this study is thus to investigate the impact of dynamic capabilities on the performance of Thai exporting firms. The study follows quantitative research design using survey method with statistical treatment. Given the extant definitions of dynamic capabilities, contextual ambidexterity, an ability of the organization to pursue alignment and adaptation simultaneously, was proposed as dynamic capability in this study. Structured questionnaires were collected from key informants of Thai firms engaging in exporting $(n=102)$. Bivariate regression analysis was employed to test the hypothesis, whilst cluster analysis and one-way analysis of variance were used to explore the results. The findings indicate that dynamic capability of contextual ambidexterity significantly affected the level of export performance of the participating firms. By clustering all participating firms according to their level of alignment and adaptation, 'highly ambidextrous' firms (i.e., high scores on both alignment and adaptation) outperformed the firms in the other combinations. The study offers practical suggestions on how exporting firms can improve profitability and performance by pursuing the proper combinations of alignment and adaptability corresponding to the dynamism of their export markets. The main contribution of this paper is the examination of performance impact of dynamic capability in exporting context which should contribute to the future development of this line ofresearch, particularly in emerging economies.
\end{abstract}

Keywords: dynamic capabilities, contextual ambidexterity, export performance, emerging economies

\section{Introduction}

Globalization and advances in communication technology have encouraged firms to look for market opportunities internationally, not only to ensure their survival but also to sustain their competitive advantage (Sousa, 2004). In the last two decades, firms in emerging economies have played an increasingly important role in an integrated global economy. The majority of firms from these emerging economies are moving towards an outward-oriented export-led growth whilst moving away from inward-oriented import substitution policies (Yiu et al., 2007). Many of these firms are in the early stages of the internationalization process in which exporting is the primary mechanism for participating in foreign markets (Aulakh et al., 2000). For that reason, the increasing importance of export activities has led to increasing scholarly research. The growth in export performance research can also be attributed to the performance difficulties that exporters face due to intense competition in their international markets (Leonidou et al., 2002; Tooksoon \& Osman, 2010).

The primary focus of this paper is to explore performance diversity among exporters in Thailand, an emerging economy, in order to explain why some exporters perform better than others. Although export performance research is traditionally guided by the industrial organization $(\mathrm{I} / \mathrm{O})$ framework which works on the principle of strategy-environment co-alignment (Venkatraman \& Prescott, 1990), recent studies have applied the resource-based view (RBV) framework which considers a firm's internal idiosyncratic resources or capabilities to be the ultimate source of competitive advantage (Maurel, 2009; Tooksoon \& Osman, 2010; Zou et al., 2003).

In current strategic management literature, the dynamic capability perspective, an extension of the RBV, has emerged. Strategy scholars (e.g., Boccardelli \& Magnusson, 2006; Teece et al., 1997) have claimed that the dynamic capability framework explains performance diversity in firms operating in highly competitive environment better than the RBV. A dynamic capability is defined as "a firm's ability to integrate, build, and 
reconfigure internal and external competencies to address rapidly changing environments" (Teece et al., 1997, 516). Rindova and Kotha (2001) further support that competitive advantage in a fast-paced competitive environment is transient in that managers need to concentrate on renewing rather than sustaining the source of competitive advantage. Dynamic capabilities are thus considered as critical to the success of the firms in such markets (Killen \& Hunt, 2010).

Although export markets have been described as being highly competitive and therefore dynamic (Filatotchey et al., 2009), an examination of the extant literature in both dynamic capability and export marketing domains, reveals that prior related studies do not give enough attention to empirically linking these two streams of research. This is important because linking these streams allows for explaining variations among exporters in export performance. Furthermore, most of dynamic capability studies focused on a Western context, there is currently still little knowledge for Asian perspective. As a consequence, literature highlights the need to investigate the consequences of dynamic capabilities in highly competitive environments such as export markets, especially in the context of emerging economies in Asia. Therefore, this study falls under the umbrella of export marketing and strategic management research. The emerging country of interest in this study is Thailand, as it is in the midst of rapid economic growth and has been the subject of little previous study. To this end, the primary objective of this study is to understand the performance variations among exporters with particular reference to Thai firms, by applying dynamic capability perspective.

\section{Literature Review and Hypothesis Development}

\subsection{Strategic Management}

The primary mission of strategic management research is to examine why some firms perform better than others (eg., Foss \& Knudsen, 2003; Hawawini et al., 2003; Remelt et al., 1991). Strategy scholars attempt to study the performance diversity among firms, and search for the underlying factors that lead to a competitive advantage. Over the past several decades, two main research streams have emerged in strategic management literature to explain the determinants of a firm's success. The first, rooted in economic heritage, is known as Industrial Organization Economics (I/O) and the second, based upon a firm's internal resources, is labelled as the Resource-Based View (RBV) of the firm.

Initiated by Mason (1939), expanded by Bain (1956), and applied by Porter (1980) to the area of strategic management, Industrial Organization Economics (I/O) considers the industry structure as the key factor in explaining the success of a firm. The RBV, as opposed to the I/O, explains a firm's success by focusing on firm-level factors. The RBV is developed from the works of Penrose (1959) and Wernerfelt (1984) where the roles of idiosyncratic firm resources and capabilities in forming and implementing a strategy are emphasised (Dutta, Narasimhan \& Rajiv, 2005). It primarily posits that the variation in the success of the firms operating within the same industry can be explained by their internal idiosyncratic resources (Barney, 1991; Peteraf, 1993; Wernerfelt, 1984). Even though the resource-based stream of strategy research has become a dominant view in the last two decades, it has also been subject to criticisms. The major argument against the RBV is its strong internal focus and lack of emphasis on dynamics (Foss, 1998).

\subsection{The Resource-Based View of the Firm (RBV)}

According to RBV, capabilities refer to a firm's ability to integrate its resources efficiently to engage in productive activity and achieve a particular objective (Amit \& Schoemaker, 1993; Dutta et al., 2005). Capabilities can be thought of as an intermediate transformation mechanism between inputs (i.e., resources, such as R\&D expenditures) and outputs (i.e., objectives, such as new products). They are intangible and information-based processes which are specific to the firm and created over time through the interactions of a firm's resources. Unlike resources, a firm's capabilities are developed through human capital (Combe \& Greenley, 2004). Organizational capabilities can be classified as either 'operational' or 'dynamic' (Winter, 2000). Operational capability is a collection of routines or high level routines which, when combined with its implementing input flows, gives an organization's management a set of decision options for generating important outputs. Routine represents a repetitive pattern of activity. In general, an operational capability is involved in performing such activities as producing a particular product where a collection of routines is used to implement and coordinate the different tasks required to perform the activities fundamental to running a business to provide, it is argued, short-term advantage (Siggelkow, 2001). To achieve long-term success, firms need to possess not only operational capabilities to compete in existing markets, but also dynamic capabilities to reconfigure their existing resources and develop new competencies necessary to exploit emerging opportunities (Eisenhardt \& Martin, 2000; Helfat \& Peteraf, 2003; Teece et al., 1997; Winter, 2003). 


\subsection{The Dynamic Capability Perspective}

The dynamic capability perspective has its foundations in the RBV. Dynamic capabilities are not concerned with the production or the provision of products or services; rather, they build, integrate, or reconfigure operational capabilities (Eisenhardt \& Martin, 2000; Teece et al., 1997). In other words, dynamic capabilities indirectly affect output for a firm through their impact on operational capabilities (Helfat \& Peteraf, 2003).

Parallel to its development, many definitions of dynamic capability emerged in the literature. The dynamic capability definitions, however, share a common theme in that they all allude to a process of continual modification of resources in order to create difficult-to-imitate competencies which allow a firm to achieve a sustainable competitive advantage (Griffith et al., 2006). The dynamic capability perspective views the firm as a distinctive collection of both tangible and intangible resource stocks (Barney, 1991; 2001), which are converted to organizational capabilities. The development of dynamic capability perspective is viewed as expanding the applicability area of the RBV to highly competitive and rapidly changing markets. Essentially, it is argued that establishing a competitive advantage in such markets is predicated to a degree on a firm's ability to develop dynamic capabilities (Cepeda \& Vera, 2007).

The dynamic capability perspective, as opposed to the RBV, focuses on a firm's unique processes, positions and paths. It suggests that a source of competitive advantage lies in a firm's ability to adjust its resource base to address the rapidly changing environments (Arthurs \& Busenitz, 2006; Teece et al., 1997). Thus, it is generally believed that dynamic capabilities essentially enhance a firm's strategic flexibility and agility (Zahra et al., 2006) Several authors have attempted to document the possible effects of dynamic capabilities. For example, Teece et al. (1997) suggest that dynamic capabilities facilitate a firm to renew its competencies which in turn improve performance. Daniel and Wilson (2003) propose that a firm can increase its chances of succeeding in an organizational transformation effort with the presence of dynamic capabilities. Griffith et al. (2006), by emphasising the importance of knowledge-based resources, argue that the dynamic capability of market responsiveness is a significant predictor of retailer performance. Firms differ significantly in their abilities to develop resources and dynamic capabilities, which then affect firm-level performance (Rolland, Patterson, \& Ward, 2009)

\subsection{Contextual Ambidexterity as a Dynamic Capability}

In the organizational theory literature, ambidexterity is traditionally referred to as an ability of the organization to pursue two different things simultaneously, for example: low-cost and differentiation competitive strategies (Porter, 1980; 1996); manufacturing efficiency and flexibility (Adler et al., 1999) loose and tight coupling (Weick, 1976); differentiation versus integration (Lawrence \& Lorsch, 1967); variation-reducing versus variation-increasing (Burgelman, 1991); and global integration and local responsiveness (Bartlett \& Ghoshal, 1989). Organizational ambidexterity is considered by many authors as a dynamic capability. For example, Eisenhardt and Martin (2000) propose in their conceptualization of dynamic capabilities that exploitation and exploration are the two strategic logics underlying dynamic capabilities. Likewise, Ancona, Goodman, Lawrence and Tushman $(2001,658)$ suggest that dynamic capabilities "are rooted in streams of innovation-in simultaneously exploiting and exploring". To conclude, dynamic capability reflects a firm's ability to be ambidextrous or to pursue exploitation and exploration, simultaneously.

The concept of contextual ambidexterity proposed by Gibson and Birkinshaw (2004) is utilized in this research. Contextual ambidexterity, defined as the behavioural capacity to exhibit alignment and adaptability simultaneously across the entire business (Gibson \& Birkinshaw, 2004). Alignment represents the congruence of various patterns of activities in the organization to attain a common goal, whilst adaptability refers to the ability of a firm to meet a changing demand in the external environment by quickly reconfiguring activities in the organization. In other words, adaptability is the ability of the firm to adapt to the changing markets or to quickly move toward new opportunities. Though adaptability is important, successful firms are not just proactive and innovative. They are also good at exploiting the value of their proprietary assets, taking the costs out of existing operations and rolling out existing business models, this equally important capability is called alignment. For instance, whilst Nokia Corporation keeps developing new mobile technology offerings; it is also focusing on its dominant headsets franchise.

By viewing ambidexterity this way, each individual can deliver the value to existing customers in his/her own functional area, and every individual at the same time can watch for changes in the external environment and respond accordingly. Contextual ambidexterity, thus, helps a firm to avoid the coordination problems if it attempts to achieve ambidexterity through a dual structure or business units. Inherently, the developing of contextual ambidexterity is complex, time consuming, and causally ambiguous, making it very difficult for 
competitors to imitate. Hence, it can be a source of competitive advantage (Gibson \& Birkinshaw, 2004). The resurgence of interest in ambidexterity, however, can be attributed to recent empirical studies investigating the efficacy of ambidexterity and its positive effects on business performance (e.g., He \& Wong, 2004; Raisch et al., 2009; Russo \& Vurro, 2010).

\subsection{Export Performance}

Increased globalization has led to a great number of firms looking for opportunities abroad, and exporting is the most common form of entry mechanism. Export performance has increasingly gained attention from both academicians and practitioners. The growth of export performance research can be explained by the economic liberalization in world economies as well as performance difficulties confronted by most exporters (Leonidou et al., 2002). In addition, export performance is a very important concept for managers as they need to make a decision about future international commitments based on an evaluation of individual export ventures. Moreover, they must compare the performance of export activities to that of domestic ones (Madsen, 1998).

Generally, the conceptual definitions of export performance proposed in the literature include export efficiency, export effectiveness, and continuous engagement in exporting (Aaby \& Slater, 1989; Madsen, 1987; Styles, 1998). Based on his review of previous research in export performance studies, Shoham (1996) conceptually defines export performance as the composite outcome of a firm's international sales. Various reviews of export marketing literature (e.g. Madsen, 1987; Zou \& Stan, 1998) indicate a number of factors that may influence export performance. The determinants of export performance can be classified as either internal or external factors. Determinants internally to the firms can fall into three general categories: (i) organization characteristics; (ii) management characteristics; and (iii) export marketing strategies. External determinants of export performance are derived from external environmental factors (Aaby \& Slater, 1989; Zou \& Stan, 1998).

Drawing on the RBV, some studies have examined the effects of organizational capabilities on export performance (e.g., Filatotchey et al., 2009; Okpara, 2009; Raceia et al., 2007). For instance, Zou et al. (2003) link an exporter's capabilities in product development, distribution, communication, and price to export financial performance. To date, however, there is a lack of empirical study investigating export performance variations from a dynamic capability perspective.

Prior empirical research on performance implications of ambidexterity tends to emphasize the domestic market context and consequently ignores the international markets. It is therefore worthwhile to extend these implications to export markets characterised as highly competitive. Therefore, based on the prior empirical evidence showing significant affect of (contextual) ambidexterity on performance, the following hypothesis is postulated:

Hypothesis: Contextual ambidexterity is positively related to export performance.

\section{Methodology}

The unit of analysis in this research is at the firm level. This is because the primary objective of this study is to examine the performance diversity among exporters in Thailand and to compare the findings with similar research (e.g., Cadogan et al., 2002; Griffith et al., 2006; Jantunen et al., 2005; Menguc \& Auh, 2006). A structured questionnaire was collected from key informants who possessed specific knowledge in export operation of Thai companies engaging in exporting.

The systematic sampling method was employed in this study; every $2^{\text {nd }}$ name on the list was automatically selected from the sampling frame, Thailand's Exporter Selected List, after the initial starting point had been randomly determined. A total of 700 names were selected from the list of 1,400. From these questionnaires, 102 $(\mathrm{n}=102)$ were returned achieving a response rate of 14.5 percent. The sample size of 102 was sufficient based on the statistical approach and the sample size from similar studies.

\subsection{Measurement Model}

Information regarding key constructs and their corresponding scales was obtained by searching the relevant literature; therefore, all constructs were measured using existing scales drawn from literature with some adjustments to the international context. The two constructs used were measured as follows.

Dynamic Capability of Contextual Ambidexterity. With regard to the conceptualization of contextual ambidexterity emphasizing the simultaneous pursuit of alignment and adaptability, Gibson and Birkinshaw (2004) propose that contextual ambidexterity is captured by multiplicative interaction (product term) of alignment and adaptability, which reflects the argument that these two capacities are independent and non-substitutable and they add value to each other to improve firm performance. Three items are used to measure alignment, and three 
items are used to measure adaptability, and these two dimensions were reported to have reliability coefficients of 0.72 and 0.70 respectively which was satisfactory according to the guidelines suggested by Nunnally (1978). Alignment was captured by asking senior managers of export operation the degree to which they agreed with the following: (1) "the management systems in our export operation work coherently to support the overall objectives of the firm", (2) "the management systems in our export operation cause us to waste resources (e.g., finanical resources, human resources, etc.) on unproductive activities" (reversed), and (3) "people in our export operation often end up working at cross-purposes because our management systems give them conflicting objectives" (reversed). Adaptability was captured by asking senior managers of export operation the degree to which they agreed with the following: (1) "the management systems in our export operation are flexible enough to allow us to respond quickly to changes in our markets", (2) "the management systems in our export operation encourage people to challenge outmoded traditions/practices/sacred cows", and (3) "the management systems in our export operation evolve rapidly in response to shifts in our export business priorities".

Export Performance. The present study adopted a seven-item subjective scale from Jantunen et al. (2005) to assess the level of satisfaction of respondents in their export operation on seven different dimensions of performance which have been widely used in prior research. These items included sale volume, market share, profitability, market entry, development of image, development of know-how, and overall performance. In addition, Shoham (1998) also supports using multiple items to operationalize export performance. The seven-item scale reported a composite Cronbach alpha of 0.80 .

\section{Results}

The companies that formed the basis for the survey were drawn from two industries: Automotive parts and accessories (52.9\%); and electrical parts and products (47.1\%). Most of the firms classified their products as industrial goods (78.4\%). The major export market was the Middle East and Asia (65.7\%), followed by Europe (16.7\%), America (9.8\%), Oceania (3.9\%), and Africa (3.9\%). Additionally, most of the firms exported their product directly (not through agents) $(72.6 \%)$. The annual turnover of most firms fell under 50 million baht (30.4\%), followed by 101 to 250 million baht (23.5\%), 51 to 100 million baht (15.7\%), 251 to 500 million baht $(12.7 \%), 501$ to 1,000 million baht $(8.9 \%)$, and 1,000 million baht and over $(8.8 \%)$. The majority of the firms had export departments (75.5\%). The mean year of establishment was 1986.5 and the mean number of employees was 214. Examining the position of the key informants revealed that $48.1 \%$ were export and marketing managers, $25.5 \%$ were management directors, $12.7 \%$ were general managers, $4.9 \%$ were owners, and the remaining $8.8 \%$ were from other positions.

\subsection{Initial Analysis}

Each of the items was first checked for skewness and kurtosis, and the presence of normality and outliers. In order to obtain a holistic picture of each of the variables across a small range of scores (1-7), histograms and box plots were deemed appropriate. The histograms and box plots were visually examined. Furthermore, an examination of another regression assumption of independent errors which requires no serial correlations between errors in regression model was necessary. Regarding the assumption of independent errors, the residuals should be uncorrelated for any two observations in regression (Field, 2005). The Durbin-Watson test was used to assess this assumption. A test value close to 2 indicates that the residuals are uncorrelated (Field, 2005). The results of the regression analysis in Table 1 revealed that the Durbin-Watson statistics was close to 2.0, therefore, the assumption of independent errors was not violated.

\subsection{Exploratory Factor Analysis}

Convergent validity in this study was assessed by analysing the factor structures. The 13 items used to measure two constructs were subjected to exploratory factor analysis using SPSS. Ticehurst and Veal (2000) suggest that variables which have a contamination of more than .30 on another factor should be discarded. Therefore, as per suggestions by Ticehurst and Veal (2000), this study follows these 'rules': a cut-off point for item loading of .50 and cross-loading of not more than .30. Item one in alignment was deleted due to the low factor loading and high cross-factor loading on the other component. Each of the items loaded cleanly on one component except for the market share item which showed high factor loading on two components; therefore, this item was deleted.

\subsection{Hypothesis Testing Results}

Bivariate regression analysis was used to test the hypothesis in this study. The bivariate regression results from table I revealed that contextual ambidexterity was a significant predictor of export performance $(\mathrm{b}=.333, \mathrm{t}=$ $3.527, \mathrm{p}<.01)$, and it explained $11.1 \%(\mathrm{R} 2=.111)$ of the variation in export performance. Ambidextrous firms represent the firms with a capacity to pursue alignment and adaptability simultaneously leading to greater 
performance compared to firms with different combinations of alignment and adaptability. Therefore, in order to further verify the effects of contextual ambidexterity on export performance and gain additional insights, another statistically analytical technique 'cluster analysis' is performed.

Table 1. Results of bivariate regression analysis

\begin{tabular}{ccccccc}
\hline $\begin{array}{c}\text { Independent } \\
\text { Variable }\end{array}$ & $\begin{array}{c}\text { Dependent } \\
\text { Variable }\end{array}$ & Beta & t-Value & Sig T & $\mathbf{R}^{2}$ & Durbin-Watson \\
\hline $\begin{array}{c}\text { Contextual } \\
\text { Ambidexterity }\end{array}$ & Export Performance & $.333^{* *}$ & 3.527 & .001 & .111 & 2.007 \\
\hline
\end{tabular}

Note**** The results are highly significant at the 0.001 level.

\subsection{Cluster Analysis}

The different combinations between alignment and adaptability pursued by Thai exporters are depicted graphically in figure 1. This graph revealed some important points. First, majority of the firms clustered around the upper right area which indicated that they scored high on both alignment and adaptability. Additionally, there was a group of firms clustered toward the middle, whilst there were some firms pursuing different combinations of alignment and adaptability along the different positions throughout the graph. This suggested that it was possible to cluster these firms into some meaningful group.

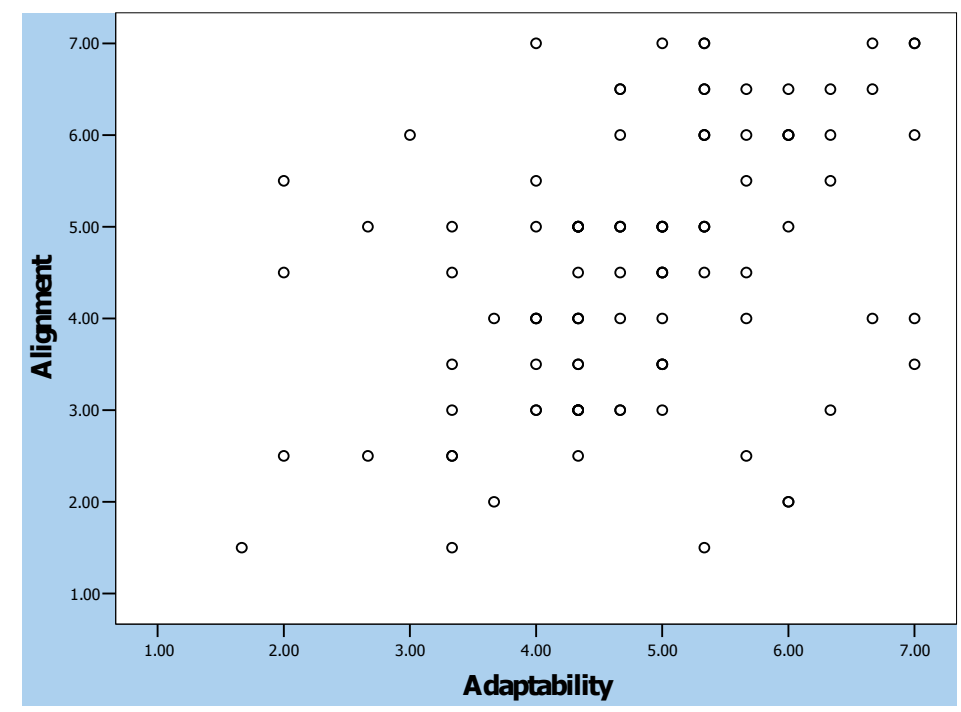

Figure 1. Plot of alignment versus adaptability

By performing the K-mean algorithm (Hartigan \& Wong, 1979) cluster analysis, the four-group model provided the best fit. The scores of alignment and adaptability for each group are shown in the Table 2. Group 1, which had high scores on both alignment and adaptability, consisted of 42 'highly ambidextrous' firms. Group 2, which had higher scores on adaptability than alignment, consisted of 21 'adaptive' firms. Group 3, which had average scores on both alignment and adaptability, consisted of 26 'moderately ambidextrous' firms, and Group 4, represented a group of firms with higher score on alignment than adaptability, consisted of 13 'aligned' firms. 
Table 2. Results of cluster analysis

\begin{tabular}{cccc}
\hline \multirow{2}{*}{ Group } & \multicolumn{3}{c}{ Group Rating } \\
\cline { 2 - 4 } & Alignment & Adaptability & Number of firms \\
\hline 1 & 5.88 & 5.39 & 42 \\
2 & 3.74 & 5.56 & 21 \\
3 & 2.88 & 3.88 & 26 \\
4 & 4.73 & 3.41 & 13 \\
\hline
\end{tabular}

To examine whether there were any significant differences in export performance among the four groups, a one-way ANOVA was performed. As highlighted in Table 3, there was a significant difference in export performance among the four groups $(\mathrm{F}=7.71, \mathrm{p}<.001)$. In other words, the different levels in the firms' contextual ambidexterity led to different levels of export performance of the firms.

Table 3. ANOVA results: export performance mean scores (Standard Deviations) in each group

\begin{tabular}{cccccccc}
\hline $\begin{array}{c}\text { Dependent } \\
\text { Variable }\end{array}$ & Group 1 & Group 2 & Group 3 & Group 4 & F & Sig $\begin{array}{c}\text { Levene } \\
\text { statistic }\end{array} \begin{array}{c}\text { Levene } \\
\text { statistic } \\
\text { Sig. }\end{array}$ \\
\hline $\begin{array}{c}\text { Export } \\
\text { Performance }\end{array}$ & 4.75 & 4.68 & 4.00 & 3.42 & $7.71^{* * *}$ & .000 & .75 \\
\hline
\end{tabular}

Note***The results are highly significant at the 0.001 level.

Furthermore, in order to examine the order of each group in terms of export performance level, the post-hoc pair comparison was performed. Scheffe post-hoc test showed that group 1 (highly ambidextrous) reported significantly higher export performance than that of group 3 (moderately ambidextrous) and group 4 (aligned); however, a non-significant difference was found in export performance between group 1 (highly ambidextrous) and group 2 (adaptive).

\section{Discussion and Implications}

The results of the regression analysis (see Table 1) suggested that contextual ambidexterity is a significant predictor of export performance. That is, successful firms were able to simultaneously pursue alignment and adaptability. These findings also reinforce the view that a dynamic capability in general and the dynamic capability of contextual ambidexterity in particular lead to superior performance (Gibson \& Birkinshaw, 2004; Teece, 2007). Specifically, in dynamic markets (i.e., export markets), firms with contextual ambidexterity are better able to compete in the marketplace. However, as the firms can possess different degrees of ambidexterity, this study further examined the effect of contextual ambidexterity on export performance by clustering all participating firms around four meaningful groups representing different combinations of alignment and adaptability. The cluster analysis revealed that most of the participating firms possess high levels of both alignment and adaptability, followed by the group of exporters who possess a little higher level of adaptability than alignment (see Table 2). These findings suggest that firms operating in an unstable environment tend to be more adaptive to the changes occurring in the market.

Based on the one-way ANOVA results shown in Table 3, the significant differences in the level of export performance were found among the four groups. Furthermore, in order to reveal the order of the performance level among four groups, post-hoc paired comparison test was conducted. The results from post-hoc paired comparison test suggested that highly ambidextrous firms perform significantly better than moderately ambidextrous firms and aligned firms, but there is no significant difference in export performance level between highly ambidextrous firms and adaptive firms. These findings are interpreted based on Gibson and Birkinshaw's (2004) comments that although contextual ambidexterity is argued to lead to greater performance outcomes, the level of dynamism in different industries must be taken into consideration. For example, in a highly stable market, businesses with the highest alignment may be the best performers. Therefore, it is argued that contextual ambidexterity positively influences export performance in the export market, though more emphasis on adaptability may be necessary in very unstable markets (Gibson \& Birkinshaw, 2004; Ireland \& Webb, 2007). 
This study provides several important implications to at least two research domains: (i) strategic management; and (ii) export marketing. It is among the first studies to validate the relationship between a dynamic capability and business performance and between contextual ambidexterity and export performance in emerging countries. The findings also have implications for management. The influence of contextual ambidexterity on export performance guides management in the export industry to pursue the appropriate combinations of alignment and adaptability. That is, where possible, firms should avoid excessively emphasizing alignment at the expense of adaptability. According to the findings, the suggested strategy is to simultaneously pursue high levels of both alignment and adaptability or to have slightly more emphasis on adaptability over alignment. It appears that contextual ambidexterity as a dynamic capability rests on the ability of the firms to simultaneously achieve alignment in their current operation and adaptation to emerging threats and opportunities. Practically speaking, senior managers play a key role in fostering contextual ambidexterity. Developing these dynamic capabilities of contextual ambidexterity is a central task of executive leadership. As previous research has shown, employees often focus more on alignment than adaptability activities as they are reluctant to learn the new skills to meet changing demands in the external environment. Senior leaders of export operation should thus establish a vision and values that justify contextual ambidexterity. Every employee should be aware of the importance of the simultaneous pursuit of alignment and adaptation. Senior leaders can reinforce ambidextrous behaviors of their workers by establishing corresponding formal reward and performance evaluation systems. Nonetheless, contextual ambidexterity is not created just through vision statement or formal structure. Supportive context in which each individual employee makes choices about where and how to focus his or her energy is also important. Senior management team should become a characteristic displayed by everyone in the organization.

\section{Future Research}

Contextual ambidexterity was argued to be a dynamic capability, based on the extant definitions of dynamic capability in the literature. Future research may propose different operationalizations of dynamic capabilities by either generating a new scale to capture the dimensions of dynamic capability or proposing different constructs other than contextual ambidexterity to represent dynamic capability such as reconfiguring capabilities (Jantunen et al., 2005), market responsiveness (Griffith et al., 2006), or sourcing relationship (Weeks, 2009).

Although subjective measures of export performance are preferred when respondents are reluctant to provide objective financial data and it is argued to accurately reflect objective measures (Jantunen et al, 2005; Lumpkin $\&$ Dess, 2001), future research in export performance can use subjective measures along with objective measures given their complementary nature.

\section{References}

Aaby, N. E., \& Slater, S. F. (1989). Management Influences on Export Performance: A Review of the Empirical Literature 1978-1988. International Marketing Review, 6(4), 7-26. http://dx.doi.org/10.1108/EUM0000000001516

Adler, P., Goldoftas, B., \& Levine, D. (1999). Flexibility versus efficiency? A case study of model changeover, in Toyota production system. Organization Science, 10(1), 43-68. http://dx.doi.org/10.1287/orsc.10.1.43

Amit, R., \& Schoemaker, P. (1993). Strategic assets and organizational rent. Strategic Management Journal, 14(1), 33-46. http://dx.doi.org/10.1002/smj.4250140105

Ancona, D. G., Goodman, P. S., Lawrence, B. S., \& Tushman, M. L. (2001). Time: A new research lens. Academic of Management Review, 26(4), 645-663. http://dx.doi.org/10.5465/AMR.2001.5393903

Arthurs, J. D., \& Busenitz, L. W. (2006). Dynamic capabilities and venture performance: The effects of venture capitalists. Journal of Business Venturing, 21(2), 195-215. http://dx.doi.org/10.1016/j.jbusvent.2005.04.004

Aulakh, P., Kotabe, M., \& Teegen, H. (2000). Export strategies and performance of firms from emerging economies. Academy of Management Journal, 43(3), 342-362. http://dx.doi.org/10.2307/1556399

Bain, J. S. (1956). Barriers to new competition. Cambridge, MA: Harvard University Press.

Barney, J. B. (1991). Firm resources and sustained competitive advantage. Journal of Management, 17(1), 99-120. http://dx.doi.org/10.1177/014920639101700108

Barney, J. B. (2001). Resource-based theories of competitive advantage: A ten year retrospective on the $\begin{array}{llll}\text { resource-based view. Journal of } & \text { Management, 27(6), }\end{array}$ http://dx.doi.org/10.1177/014920630102700602

Bartlett, C. A., \& Ghoshal, S. (1989). Managing across borders: The transactional solution. Boston: Harvard business school press. 
Boccardelli, P., \& Magnusson, M. G. (2006). Dynamic capabilities in early-phase entrepreneurship. Knowledge and Process Management, 13(3), 162-174. http://dx.doi.org/10.1002/kpm.255

Burgelman, R. A. (1991). Intraorganizational ecology of strategy making and organizational adaptation: Theory and field research. Organization Science, 2(3), 239-262. http://dx.doi.org/10.1287/orsc.2.3.239

Cadogan, J. W., Diamantopoulos, A., \& Siguaw, J. A. (2002). Export market-oriented activities: Their antecedents and performance consequences. Journal of International Business Studies, 33(3), 615-626. http://dx.doi.org/10.1057/palgrave.jibs.8491036

Cepeda, G., \& Vera, D. (2007). Dynamic Capabilities and Operational Capabilities: A knowledge Perspective. Journal of Business Research, 60, 426-437. http://dx.doi.org/10.1016/j.jbusres.2007.01.013

Combe, I. A., \& Greenley, G. E. (2004). Capabilities for strategic flexibility: A cognitive content framework. European Journal of Marketing, 38(11), 1456-1480. http://dx.doi.org/10.1108/03090560410560191

Daniel, E. M., \& Wilson, H. N. (2003). The role of dynamic capabilities in e-business transformation. European Journal of Information Systems, 12(4), 282-296. http://dx.doi.org/10.1057/palgrave.ejis.3000478

Dutta, S., Narasimhan, O., \& Rajiv, S. (2005). Conceptualizing and measuring capabilities: Methodology and empirical application. Strategic Management Journal, 26(3), 277-286. http://dx.doi.org/10.1002/smj.442

Eisenhardt, K. M., \& Martin, J. A. (2000). Dynamic capabilities: What are they? Strategic Management Journal, $21(10)$ 1105-1121. http://dx.doi.org/10.1002/1097-0266(200010/11)21:10/11<1105::AID-SMJ133>3.0.CO;2-E

Field, A. (2005). Discovering statistics using SPSS (2nd ed.). London: Sage.

Filatotchey, I., Liu, X., Buck, T., \& Wright, M. (2009). The export orientation and export performance of high-technology SMEs in emerging markets: The effects of knowledge transfer by returnee entrepreneurs. Journal of International Business Studies, 40(6), 1005-1021. http://dx.doi.org/10.1057/jibs.2008.105

Foss, N. J. (1998). The resource-based perspective: An assessment and diagnosis of problems. Scandinavian Journal of Management, 14, 133-149. http://dx.doi.org/10.1016/S0956-5221(97)00030-4

Foss, N. J., \& Knudsen, T. (2003). The resource-based tangle: Toward a sustainable explanation of competitive advantage. Managerial and Decision Economics, 24(4), 291-307. http://dx.doi.org/10.1002/mde.1122

Gibson, C. B., \& Birkinshaw, J. (2004). The antecedents, consequences, and mediating role of organizational ambidexterity. Academy of Management Journal, 47(2), 209-226. http://dx.doi.org/10.2307/20159573

Griffith, D. A., Noble, S. M., \& Chen, Q. (2006). The performance implications of entrepreneurial proclivity: A dynamic capabilities approach. Journal of Retailing, 82(1), 51-62. http://dx.doi.org/10.1016/j.jretai.2005.11.007

Hartigan, J. A., \& Wong, M. A. (1979). A K-means clustering algorithm. Applied Statistics, 28, 100-108. http://dx.doi.org/10.2307/2346830

Hawawini, G., Subramanian, V., \& Verdin, P. (2003). Is performance driven by industry or firm-specific factors? A new look at the evidence. Strategic Management Journal, 24(1), 1-14. http://dx.doi.org/10.1002/smj.278

He, Z. L., \& Wong, P. K. (2004). Exploration vs. Exploitation: An Empirical Test of the Ambidexterity Hypothesis. Organization Science, 15(4), 481-495. http://dx.doi.org/10.1287/orsc.1040.0078

Helfat, C. E., \& Peteraf, M. A. (2003). The dynamic resource-based view: Capability lifecycles. Strategic Management Journal, 24(10), 997-1010. http://dx.doi.org/10.1002/smj.332

Ireland, R. D., \& Webb, J. W. (2007). Strategic entrepreneurship: Creating competitive advantage through streams of innovation. Business Horizons, 50(1), 49-59. http://dx.doi.org/10.1016/j.bushor.2006.06.002

Jantunen, A. P., Saarenketo, K. S., \& Kylaheiko, K. (2005). Entrepreneurial Orientation, Dynamic Capabilities, and international performance. Journal of International Entrepreneurship, 5(3), 223-243. http://dx.doi.org/10.1007/s10843-005-1133-2

Killen, C. P., \& Hunt, R. A. (2010). Dynamic capability through project portfolio management in service and manufacturing industries. International Journal of Managing Projects in Business, 3(1), 157-169. http://dx.doi.org/10.1108/17538371011014062

Lawrence, P. R., \& Lorsch, J. W. (1967). Organizations and environment. MA: Addison-Wesley, Reading.

Leonidou, L. C., Katsikeas, C. S., \& Samiee, S. (2002). Marketing strategy determinants of export performance: 
A meta-analysis. Journal of Business Research, 55(1), 51-67. http://dx.doi.org/10.1016/S0148-2963(00)00133-8

Lumpkin, G. T., \& Dess, G. G. (1996). Clarifying the entrepreneurial orientation construct and linking it to performance. The Academy of Management Review, 21(1), 135-172. http://dx.doi.org/10.5465/AMR.1996.9602161568

Madsen, T. K. (1987). Empirical export performance studies: A review of conceptualizations and findings. Advances in International Marketing, 2(1), 177-198.

Madsen, T. K. (1998). Executive insights: Managerial judgment of export performance. Journal of International Marketing, 6(3), 82-94.

Mason, E. S. (1939). Price and production policies of large-scale enterprises. American Economic Review, 29(1), 61-74.

Maurel, C. (2009). Determinants of export performance in French wine SMEs. International Journal of Wine Business Research, 21(2), 118-142. http://dx.doi.org/10.1108/17511060910967971

Menguc, B., \& Auh, S. (2006). Creating a firm-level dynamic capability through capitalising on market orientation and innovativeness. Journal of the Academy of Marketing Science, 34(1), 63-73. http://dx.doi.org/10.1177/0092070305281090

Nunnally, J. C. (1978). Psychometric Theory (2nd ed.). New York: McGraw-Hill.

Okpara, J. O. (2009). Strategic choices, export orientation and export performance of SMEs in Nigeria. Management Decision, 47(8), 1281-1299. http://dx.doi.org/10.1108/00251740910984541

Penrose, E. (1959). The Theory of Growth of the Firm. Oxford: Blackwell.

Peteraf, M. A. (1993). The cornerstones of competitive advantage: Resource-based view. Strategic Management Journal, 14(3), 179-191. http://dx.doi.org/10.1002/smj.4250140303

Porter, M. E. (1980). Competitive strategy: Techniques for analysing industries. New York: The Free Press.

Porter, M. E. (1996). What is strategy. Harvard Business Review, 74(6), 61-81.

Racela, O. C., Chaikittisilpa, C., \& Amornrat, T. (2007). Market orientation, international business relationships and perceived export performance. International Marketing Review, 24(2), 144-163.

Raisch, S., Birkinshaw, J., Probst, G., \& Tushman, M. L. (2009). Organizational ambidexterity: balancing exploitation and exploration for sustained performance. Organization Science, 20(4), 685-695. http://dx.doi.org/10.1287/orsc.1090.0428

Remelt, R. P., Schendel, D., \& Teece, D. J. (1991). Strategic management and economics. Strategic Management Journal, 12, 5-29. http://dx.doi.org/10.1002/smj.4250121003

Rindova, V. P., \& Kotha, S. (2001). Continuous 'morphing': Competing through dynamic capabilities, form, and function. Academy of Management, 44(6), 1263-1280. http://dx.doi.org/10.2307/3069400

Rolland, E., Patterson, R. A., \& Ward, K. F. (2009). Dynamic Capabilities and e-Service. Canadian Journal of Administrative Sciences, 26(4), 301-315. http://dx.doi.org/10.1002/cjas.117

Russo, A., \& Vurro, C. (2010). Cross-boundary ambidexterity: Balancing exploration and exploitation in the fuel cell industry. European Management Review, 7(1), 30-45. http://dx.doi.org/10.1057/emr.2010.2

Shoham, A. (1996). Marketing-mix standardisation: Determinants of export performance. Journal of Global Marketing, 10(2), 53-73. http://dx.doi.org/10.1300/J042v10n02_04

Shoham, A. (1998). Export performance: A conceptualization and empirical assessment. Journal of International marketing, 6(3), 59-68.

Siggelkow, N. (2001). Change in the presence of fit: The rise, the fall, and the renaissance of Liz Claiborne. Academy of Management Journal, 44(4), 838-857. http://dx.doi.org/10.2307/3069418

Sousa, C. M. P. (2004). Export Performance Measurement: An Evaluation of the Empirical Research in the Literature. Academy of Marketing Science Review, 9, 1-22.

Teece, D. J. (2007). Explicating Dynamic Capabilities: The Nature and Microfoundations of Sustainable Enterprise Performance. Strategic Management Journal, 28, 1319-1350. http://dx.doi.org/10.1002/smj.640

Teece, D. J., Pisano, G., \& Shuen, A. (1997). Dynamic capabilities and strategic management. Strategic 


\section{Management}

Journal,

18(7),

509-533. http://dx.doi.org/10.1002/(SICI)1097-0266(199708)18:7<509::AID-SMJ882>3.0.CO;2-Z

Ticehurst, G., \& Veal, A. (2000). Business research Methods: A managerial approach. South Melbourne: Longman.

Tooksoon, P., \& Mohamad, O. (2010). Marketing capability and export performance: the moderating effect of export dependence. The South East Asian Journal of Management, 4(1), 39-52.

Weeks, M. R. (2009). Sourcing practices and innovation: Evidence from the auto industry on the sourcing relationship as a dynamic capability. Innovation: Management, Policy \& Practice, 11, 304-326. http://dx.doi.org/10.5172/impp.11.3.304

Weick, K. E. (1976). Educational organizations as loosely coupled systems. Administrative Science Quarterly, 21(1), 1-19. http://dx.doi.org/10.2307/2391875

Wernerfelt, B. (1984). A resource-based view of the firm. Strategic Management Journal, 5(2), 171-180. http://dx.doi.org/10.1002/smj.4250050207

Yiu, D. W., Lau, C., \& Bruton, G. D. (2007). International venturing by emerging economy firms: The effects of firm capabilities, home country networks, and corporate entrepreneurship. Journal of International Business Studies, 38, 519-540. http://dx.doi.org/10.1057/palgrave.jibs.8400278

Zahra, S. A., Sapienza, H. J., \& Davidson, P. (2006). Entrepreneurship and dynamic capabilities: A review, model and research agenda. The Journal of Management, 43(4), 917-955.

Zou, S., \& Stan, S. (1998). The Determinants of export performance: A review of the empirical literature between 1987-1997. International Marketing Review, 15(5), 333-356. http://dx.doi.org/10.1108/02651339810236290

Zou, S., Fang, E., \& Zhao, S. (2003). The effect of export marketing capabilities on export performance: An investigation of Chinese exporters. Journal of International Marketing, 11(4), 32-66. http://dx.doi.org/10.1509/jimk.11.4.32.20145

\section{Copyrights}

Copyright for this article is retained by the author(s), with first publication rights granted to the journal.

This is an open-access article distributed under the terms and conditions of the Creative Commons Attribution license (http://creativecommons.org/licenses/by/3.0/). 